\title{
Aplikasi Jamur Entomopatogen (Beauveria bassiana) dan Ekstrak Tumbuhan (Ageratum conyzoides L.) terhadap Larva Plutella xylostella $\mathrm{L}$.
}

\section{Application of the Entomopatogenic fungi Beauveria bassiana and Plant Extracts Ageratum conyzoides 1 . Against the Larva of Plutella xylostella $L$.}

\author{
Irsyad Muhammad Ardan, Dadi Nurdiana, Siti Syarah Maesyaroh \\ Program Studi Agroteknologi, Fakultas Pertanian, Universitas Garut \\ Jalan Raya samarang Nomor 52A, Tarogong Kaler, Garut 44151. \\ e-mail:dadi_nurdiana@uniga.ac.id
}

\begin{abstract}
ABSTRAK
Penelitian ini bertujuan untuk mengetahui pengaruh jamur entomopatogen Beauvaria bassiana dan ekstrak tumbuhan Ageratum conyzoides L. terhadap larva Plutella xylostella L. Percobaan dilaksanakan di laboratorium Balai Benih Hortikultura (BBH) Kecamatan Cisurupan Kabupaten Garut, pada bulan April sampai Oktober 2018. Penelitian menggunakan Rancangan Acak Lengkap (RAL) dengan tiga ulangan. Perlakuan yang digunakan adalah Jamur B. bassiana (konsentrasi $0 \% ; 7,5 \% ; 10 \% ; 12,5 \% ; 15 \%$ ) dan A. conyzoides (konsentrasi 7,5; $10 ; 12,5 \%)$. Hasil penelitian menunjukkan pengaruh aplikasi jamur B. bassiana pada konsentrasi $10 \%$ merupakan konsentrasi paling efektif dan efisien terhadap mortalitas larva, perubahan kesehatan larva dan meminimalisir stadia lanjut larva sedangkan pada aplikasi A. conyzoides konsentrasi $12,5 \%$ merupakan dosis yang paling tinggi tingkat mortalitas, perubahan kesehatan, dan meminimalisir perubahan stadia lanjut larva P. xylostella. Pengaruh aplikasi B. bassiana cenderung lebih lambat dalam menurunkan populasi larva P. xylostella dibanding aplikasi A. conyzoides.
\end{abstract}

Kata kunci : Beauvaria bassiana, Ageratum conyzoides L., Plutella xylostella L.

\begin{abstract}
This research was purposed to study the effect of entomopathogenic fungi Beauvaria bassiana and extract of Ageratum conyzoides L. on Plutella xylostella L. larvae. The experiment was carried out in the Horticultural Seed Center (BBH) laboratory at Cisurupan Sub district, Garut Regency, from April to October 2018. The treatments that consisted of consentration fungus B. bassiana of 0\%; 7,5\%; $10 \% ; 12,5 \% ; 15 \%$ and extract consentration A. conyzoides 7,5\%; 10\%; 12,5\% were arranged in Randomized Complete Design $(R C D)$ with three replications. The results showed the application of fungus B. bassiana at concentration $10 \%$ was the most efficient and effective concentration on larval mortality, the health of
\end{abstract}


larvae and larval growth stage whilst the application A. conyzoides $12.5 \%$ caused the highest mortality rates, health changes, and minimize larval growth stage of P. xylostella. The application of $B$. bassiana showed decreasing the larval populations of $P$. xylostella higher then the applications of A. conyzoides.

Keywords: Beauveria bassiana, Ageratum conyzoides L., Plutella xylostella L.

\section{PENDAHULUAN}

Kubis (Brassicae oleracea) adalah salah satu komoditas sayuran yang mempunyai nilai ekonomi tinggi. Namun, dalam budidaya tanaman tersebut tidak sedikit tantangan dan kendala yang dihadapi, khususnya masalah serangan hama dan penyakit yang dapat menggagalkan panen. Masalah utama yang dihadapi dalam usaha tani kubis adalah serangan hama. Larva Plutella xylostella L. adalah hama utama yang sangat merusak tanaman Brassicaceae, terutama kubis, sawi, dan caisin di Indonesia (Kartosuwondo 1994; Winasa \& Herlinda 2003).

Larva ini dikenal juga dengan nama ulat tritip, dan menjadi salah satu hama yang paling ditakuti oleh petani kubis. Serangan berat bisa mengakibatkan kerugian yang sangat signifikan, terutama menurunnya kualitas dan kuantitas produksi. Berdasarkan data dari Badan Pusat Statistik dan Direktorat Jenderal Hortikultura, produktivitas kubis dalam skala nasional pada tahun 2015 mencapai 22,33 ton per hektar sedangkan tahun 2016 mencapai 21,04 ton per hektar. Serangan hama tersebut membuat para petani sangat terpukul, karena tingkat kerusakan tanamannya bisa sampai 90\%. Dampaknya harga sejumlah komoditas kubis-kubisan mengalami penurunan. Harga sawi yang biasanya Rp 2.500 sampai 4.000 per kilogram jadi Rp 1.000 per kilogram (Husodo, 2017).

Sastrosiswojo dan Setiawati (1993) juga menyatakan bahwa larva $P$. xylostella menyerang tanaman kubis yang muda sebelum membentuk krop. Tingkat populasi larva yang biasanya terjadi pada 6 sampai 8 minggu setelah tanam, dan dalam kondisi seperti ini serangan dapat mengakibatkan kerusakan berat pada tanaman kubis. Kehilangan hasil yang ditimbulkan oleh larva $P$. xylostella pada tanaman kubis dapat mencapai 58 sampai 100\% (Rukmana, 1994).

Pengendalian utama larva $P$. xylostella pada tanaman kubis secara umum 
para petani menggunakan insektisida sintetis yang tidak menggunakan kaidahkaidah penggunaan pestisida secara bijaksana. Akibat penggunaan insektisida yang intensif tersebut muncul masalah baru seperti : (a) resurgensi larva terhadap Asefat, Permetrin dan Kuinalfos, (b) larva menjadi resisten terhadap beberapa jenis insektisida kimia dan mikroba, (c) terganggunya kehidupan dan peranan parasitoid Diadegma semiclausum sebagai musuh alami penting larva $P$. xylostella dan (d) residu pestisida yang terkandung dalam sayuran kubis dapat membahayakan konsumen (Sastrosiswojo, $d k k$. 2005).

Pengaruh negatif dari pestisida tersebut diperlukan metode pengendalian yang lebih aman terhadap lingkungan. Hal ini sesuai dengan konsep Pengendalian Hama Terpadu (PHT) yang menyatakan bahwa pengendalian organisme pengganggu tumbuhan dilaksanakan dengan mempertahankan kelestarian lingkungan, aman bagi produsen dan konsumen, meningkatkan kesejahteraan petani, membatasi penggunaan pestisida sesedikit mungkin, tetapi sasaran kualitas dan kuantitas produksi kubis masih dapat dicapai (Sastrosiswojo, dkk. 2005). Salah satu alternatif pengendalian larva $P$. xylostella adalah pemanfaatan jamur entomopatogen Beauveria bassiana penyebab penyakit pada serangga dan penggunaan ekstrak tumbuhan babadotan (Ageratum conyzoides L.) sebagai insektisida nabati.

Penggunaan antara agensia hayati dan pestisida nabati kini mulai dikombinasikan dan dikembangkan, namun perlu diketahui bahwa tidak semua agensia hayati dan pestisida dapat kompatibel dan sinergis jika dikombinasikan, misalnya penelitian Susanti $d k k$ (2016), dalam penelitian tersebut diuji kompatibilitas jamur entomopaogen Beauveria bassiana dan pestisida nabati ekstrak daun babadotan untuk mengendalikan hama kepik hijau. hasil penelitian Susanti $d k k$ (2016) menunjukkan bahwa ekstrak daun babadotan secara nyata mengahambat perkecambahan konidia jamur B. bassiana. Berdasarkan pemikiran tersebut perlu dilakukan metode aplikasi agensia hayati dan pestisida nabati dengan berbagai konsentrasi dan diaplikasikan secara tunggal. Diharapkan metode aplikasi tersebut dapat meningkatkan mortalitas hama $P$. xylostella.

\section{METODE PENELITIAN}

Percobaan dilaksanakan di laboratorium Balai Benih hortikultura (BBH) 
Kecamatan Cisurupan Kabupaten Garut, Ketinggian tempat \pm 1100 meter di atas permukaan laut, percobaan dilaksanakan dari bulan April sampai Oktober 2018. Bahan yang digunakan antara lain isolat jamur $B$. bassiana, tumbuhan $A$. conyzoides, larutan Tween80, Aquades, Etanol 90\%, Etanol 96\%, larutan madu $10 \%$, larva $P$. xylostella dan daun kubis sebagai pakan. Alat yang digunakan antara lain timbangan, pipet tetes, Magnetic stirer, batang pengaduk, Beaker glass, erlenmeyer, gelas ukur, corong gelas, stoples, kain kassa, karet gelang, mortar, baskom, nampan, kapas, gunting, kipas, kardus, sprayer, label nama, pinset, alat tulis, dan alat pendukung lainnya.

Metode penelitian yang digunakan adalah metode eksperimental dan metode deskriptif dengan menggunakan Rancangan Acak Lengkap (RAL) satu faktor. Jumlah perlakuan terdiri atas delapan perlakuan serta tiga kali ulangan, sehingga dibutuhkan 24 plot percobaan. Perlakuan yang digunakan adalah sebagai berikut: $\mathrm{A}=$ Konsentrasi 0\% (Larutan Aquades $100 \mathrm{ml}$ ), B = Konsentrasi 7,5\% (Larutan Aquades 92,5ml + Larutan B. bassiana 7,5 ml), C = Konsentrasi 10\% (Larutan Aquades $90 \mathrm{ml}+$ Larutan B. bassiana $10 \mathrm{ml}$ ), D = Konsentrasi 12,5\% (Larutan Aquades 87,5 ml+ Larutan B. bassiana 12,5 ml), E = Konsentrasi 15\% (Larutan Aquades $85 \mathrm{ml}+$ Larutan B. bassiana $15 \mathrm{ml}$ ), F = Konsentrasi 7,5\% (Larutan Aquades 92,5 ml + Larutan conyzoides 7,5 ml), G = Konsentrasi 10\% (Larutan Aquades $90 \mathrm{ml}+$ Larutan A. conyzoides $10 \mathrm{ml}$ ), $\mathrm{H}=$ Konsentrasi 12,5\% (Larutan Aquades 87,5 ml + Larutan A. conyzoides 12,5 ml).

Penelitian dilaksanakan melalui beberapa tahap yaitu perbanyakan konidium $B$. bassiana, pembuatan ekstrak tumbuhan $A$. conyzoides, penyiapan dan pemeliharaan larva $P$. xylostella, pengujian jamur B. bassiana dan ekstrak $A$. conyzoides pada larva uji, dan pengambilan data.

\section{HASIL DAN PEMBAHASAN}

\section{Mortalitas Larva}

Hasil dari pengamatan persentase mortalitas larva didapat dari rata-rata analisis statistik menunjukkan bahwa perlakuan yang diberikan menggunakan jamur B. bassiana pada hari ke-1 dan ke-2 tidak berbeda nyata, Sejalan dengan 
hasil penelitian yang dilakukan oleh Febrina et al., (2014) aplikasi B. bassiana dengan konsentrasi 5, 10, dan 15 gram/liter setelah aplikasi 24 jam belum menunjukkan adanya larva $P$. xylostella yang mati. Aplikasi perlakuan jamur $B$. bassiana pada hari ke- 2, 3, 4, 5, 6 dan 7 memberi pengaruh yang nyata terhadap mortalitas larva $P$. xylostella. Berbeda dengan perlakuan A. conyzoides yang sudah menunjukkan kematian sejak hari ke-1. Hasil analisis data rata-rata tingkat mortalitas larva $P$. xylostella dapat dilihat pada Tabel 1.

Hasil pengamatan pada penggunaan B. bassiana didapatkan perlakuan yang paling efektif yaitu pada taraf konsentrasi $10 \%$ dan $12,5 \%$ dengan mortalitas masing-masing 76,67\% dan 83,33\%. Data menunjukkan hari ke-3 dan ke-4 setelah aplikasi pada perlakuan $12,5 \%$ tidak berbeda nyata dengan perlakuan $10 \%$ dan $15 \%$ tetapi berbeda nyata dengan perlakuan 7,5\%. Begitupun hari ke-5, 6 dan 7 menunjukkan bahwa perlakuan $10 \%$ dan 12,5\% tidak berbeda nyata dengan perlakuan $15 \%$ yang merupakan pemberian A. bassiana dengan dosis paling tinggi. Hal ini menunjukkan bahwa diperlukan pemberian konsentrasi yang tepat untuk mengendalikan larva P. xylostella. Untung (2001) menyatakan bahwa bioinsektisida diperlukan dosis yang tepat dalam penggunaannya agar hama dapat dikendalikan secara optimal. Pemberian dosis yang berlebihan akan mengakibatkan pemborosan biaya dan tidak efisien, sedangkan dosis yang dibawah anjuran akan menimbulkan hama menjadi resisten dan sulit dikendalikan.

Gambar 1 menunjukkan bahwa pada pengamatan hari ke-2 tingkat mortalitas larva $P$. xylostella pada perlakuan B. bassiana mulai terlihat ada yang mati pada konsentrasi 7,5 \%, $10 \%$, dan 12,5 \% sedangkan pada konsentrasi paling tinggi yaitu $15 \%$ belum terlihat adanya larva yang mati. Hal ini diduga larva pada tingkat konsentrasi $15 \%$ memilikidaya tahan yang cenderung lebih baik sehingga larva yang terinfeksi masih bertahan walaupun sudah menunjukkan gejala terinfeksi oleh jamur B. bassiana. Taraf perlakuan $10 \%$ pada hari ke-2 memiliki daya mortalitas paling tinggi yang diduga larva memiliki kondisi yang lebih lemah.

Kematian larva dapat terjadi dalam kurun waktu 2 sampai 5 hari setelah infeksi pertama (Novizan, 2002). Aplikasi B. bassiana dalam bentuk konidia 
dapat menginfeksi serangga melalui kutikula, sistem pencernaan, mulut dan ruasruas yang terdapat pada tubuh serangga. Spektrum serangga inang oleh $B$. bassiana meliputi, ordo Coleoptera, Lepidoptera, Hemiptera, Diptera, Homoptera, dan Orthoptera (Suprapto \& Suroso, 1998).



Gambar 1. Grafik Mortalitas Larva P. xylostella

Jamur B. bassiana didalam tubuh serangga memproduksi toksin yang disebut Beauvericin, toksin inilah yang merusak struktur membran sel sehingga serangga mati. Jamur B. bassiana akan terus melanjutkan pertumbuhan siklusnya dalam fase saprofitik. Setelah serangga inang mati, B. bassiana akan mengeluarkan antibiotik, yaitu Oosporein yang menekan populasi bakteri dalam perut serangga inang. Akhirnya seluruh tubuh serangga inang akan penuh oleh propagul $B$. bassiana. Bagian lunak dari tubuh serangga inang ditumbuhi jamur ini sampai menembus keluar dan menampakkan pertumbuhan hifa di bagian luar tubuh serangga inang yang biasa disebut "white bloom" lebih jelasnya dapat dilihat pada gambar 2. Pertumbuhan hifa eksternal akan menghasilkan konidia yang bila telah masak akan disebarkan ke lingkungan dan menginfeksi serangga sasaran baru (Wahyudi, 2008).

Taraf perlakuan jamur B. bassiana sampai hari ke-7 pada berbagai faktor terlihat mengalami kenaikan jumlah mortalitas larva $P$. xylostella. Hal ini diduga kondisi lingkungan cukup baik dalam perkembangan jamur pada inang. Akibatnya 
jamur terus tumbuh dan menginfeksi larva yang kemudian membuatlarva sakit dan mati (Lebih jelasnya dapat dilihat pada gambar 2). Terlihat semakin tinggi konsentrasi jamur B. bassiana yang diberikan maka semakin cepat dan banyak larva yang mati, namun kematian larva pada faktor ini terlihat bertahap. Berbeda dengan faktor jamur B. bassiana taraf faktor konsentrasi A. conyzoides terlihat lebih cepat membunuh larva pada awal perlakuan.

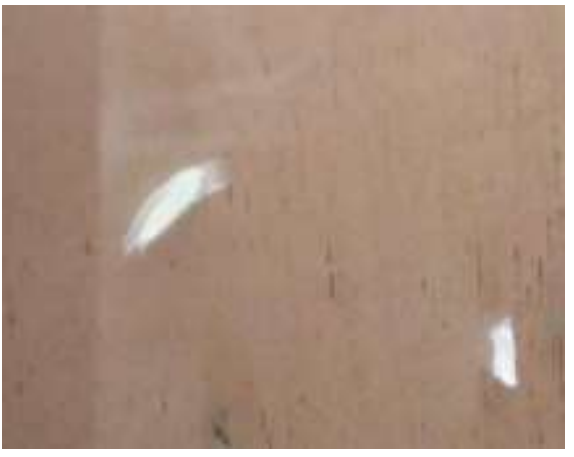

a

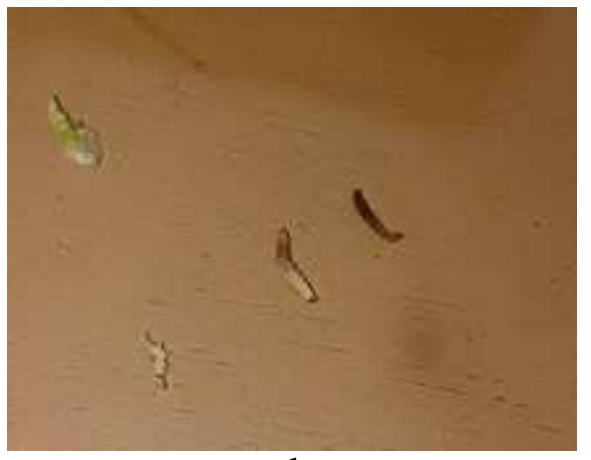

b

Gambar 2. Mortalitas Larva Akibat Perlakuan (a) Jamur B. bassiana (b)

Hasil pengamatan menunjukkan perlakuan A. conyzoides berbagai taraf konsentrasi sudah terlihat berbeda nyata pada hari ke-1 atau 24 jam setelah waktu aplikasi. Hal ini diduga daya racun dari A. conyzoides mampu membunuh sasaran karena racun yang cukup tinggi dan efektif dalam mengendalikan larva. Sesuai dengan hasil penelitian Sari et al., (2013) menunjukkan bahwa penggunaan dosis A. conyzoides berpengaruh terhadap mortalitas larva $P$. xylostella sebanyak $5 \%$ pada hari ke-1 setelah aplikasi, sedangkan dosis 500 gram mampu membunuh larva sebanyak $10 \%$.

Sebelum perlakuan larva tidak diberi makan selama 12 jam dan kemudian diberi pakan yang sudah diberi perlakuan jamur $B$. bassiana dan ekstrak tumbuhan A. conyzoides secara langsung larva tersebut terkena efek racun dari kedua bahan perlakuan tersebut, beberapa larva yang lemah berangsur mati dalam waktu 24 jam. Tabel 1 menunjukkan pengaruh konsentrasi A. conyzoides yang paling efektif yaitu pada perlakuan $\mathrm{H}$ dengan mortalitas $73,33 \%$. Konsentrasi $A$. conyzoides terlihat lebih tinggi dalam meningkatkan mortalitas larva $P$. xylostella. Semakin tinggi konsentrasi A. conyzoides yang diberikan maka semakin banyak larva yang mati. Hal ini sesuai dengan Purba (2007) yang 
mengatakan bahwa peningkatan dosis berbanding lurus dengan peningkatan bahan racun tersebut, sehingga daya bunuh semakin tinggi untuk membunuh larva.

Seperti halnya tanaman beracun lainnya, babadotan juga memiliki kemampuan sebagai insektisida nabati (racun serangga), karena dalam daun dan bunga babadotan terkandung senyawa penting atau senyawa metabolit yang bersifat sebagai insektisida seperti minyak atsiri, kumarin, plafonoid, alkaloid, saponin, dan polifenol, (Kardinan, 2004). Sistem kerja zat aktif pestisida nabati masuk melalui oral maupun kulit hama. Racunnya akan menyerang sistem pencernaan maupun syaraf sehingga dapat melumpuhkan dan mematikan hama (Marfu'ah, 2005).

Taraf perlakuan A atau faktor kontrol belum menunjukkan mortalitas pada

hari ke-1 sampai ke-4, namun setelah hari ke-5 sampai hari ke-7 terdapat larva yang mati sedangkan faktor kontrol tidak menggunakan bahan aktif apapun. Hal ini diduga kondisi larva yang lemah dan faktor stress karena habitatnya sedikit berbeda dengan di alam, itupun sudah dilakukan upaya untuk adaptasi larva. Walaupun begitu mortalitasnya masih cukup rendah dan berbeda nyata dengan perlakuan- perlakuan yang lainnya.

\section{Perubahan Kesehatan Larva}

Pengamatan perubahan kesehatan larva ditandai dengan adanya gejala infeksi yang disebabkan oleh aplikasi perlakuan jamur $B$. bassiana dan ekstrak $A$. conyzoides.

Hasil pengamatanmenunjukkan adanya gejala infeksi terhadap larva yang dapat dilihat pada table 2. Perubahan tingkat kesehatan larva $P$. xylostella pada hari ke-1 (24 jam setelah aplikasi) dengan perlakuan konsentrasi jamur B. bassiana terlihat sedikit larva yang mulai menunjukkan gejala sakit akibat infeksi jamur. Perlakuan konsentrasi $A$. conyzoides dosis $12,5 \%$ menunjukkan perubahan kesehatan larva sebesar 5,33\% pada hari ke-1 dengan ditandai gejala seperti gerakan lamban, nafsu makan berkurang, dan mulai ada larva yang berangsur mati. Perbedaan ini diduga dalam menginfeksi jasad sasaran jamur B. bassiana memerlukan waktu yang cukup lama untuk masuk menembus kutikula dan menginfeksi larva. 
Tabel 2. Hasil Analisis Perubahan Kesehatan Larva P. xylostella (ekor)

Perubahan Kesehatan Larva (ekor)

Perlakuan

Hari ke-

\begin{tabular}{lrrrrrrr}
\hline & 1 & 2 & 3 & 4 & 5 & 6 & 7 \\
\hline A $(0 \%)$ & $0,67 \mathrm{a}$ & $0,67 \mathrm{a}$ & $0,00 \mathrm{a}$ & $0,00 \mathrm{a}$ & $0,33 \mathrm{a}$ & $0,33 \mathrm{a}$ & $0,67 \mathrm{a}$ \\
$\mathrm{B}(7,5 \%$ B. bassiana $)$ & $1,67 \mathrm{a}$ & $4,00 \mathrm{~b}$ & $4,67 \mathrm{~b}$ & $4,67 \mathrm{~b}$ & $4,67 \mathrm{~b}$ & $4,67 \mathrm{~b}$ & $4,67 \mathrm{~b}$ \\
$\mathrm{C}(10 \%$ B. bassiana $)$ & $1,67 \mathrm{a}$ & $4,33 \mathrm{~b}$ & $5,33 \mathrm{~b}$ & $7,67 \mathrm{~b}$ & $7,67 \mathrm{~b}$ & $7,67 \mathrm{~b}$ & $7,67 \mathrm{~b}$ \\
D (12,5\% B. bassiana $)$ & $2,33 \mathrm{a}$ & $2,33 \mathrm{a}$ & $2,67 \mathrm{~b}$ & $3,00 \mathrm{~b}$ & $4,67 \mathrm{~b}$ & $6,33 \mathrm{~b}$ & $8,33 \mathrm{~b}$ \\
E (15\% B. bassiana $)$ & $2,00 \mathrm{a}$ & $3,67 \mathrm{~b}$ & $4,33 \mathrm{~b}$ & $5,67 \mathrm{~b}$ & $6,67 \mathrm{~b}$ & $7,33 \mathrm{~b}$ & $8,67 \mathrm{~b}$ \\
F (7,5\% A. conyzoides $)$ & $1,33 \mathrm{a}$ & $3,33 \mathrm{~b}$ & $3,00 \mathrm{~b}$ & $3,33 \mathrm{~b}$ & $3,67 \mathrm{~b}$ & $4,33 \mathrm{~b}$ & $4,33 \mathrm{~b}$ \\
G (10\% A. conyzoides $)$ & $3,00 \mathrm{~b}$ & $4,67 \mathrm{~b}$ & $5,00 \mathrm{~b}$ & $5,33 \mathrm{~b}$ & $5,33 \mathrm{~b}$ & $5,33 \mathrm{~b}$ & $5,33 \mathrm{~b}$ \\
H (12,5\% A. conyzoides $)$ & $5,33 \mathrm{~b}$ & $6,67 \mathrm{~b}$ & $7,00 \mathrm{~b}$ & $7,33 \mathrm{~b}$ & $7,33 \mathrm{~b}$ & $7,33 \mathrm{~b}$ & $7,33 \mathrm{~b}$
\end{tabular}

Keterangan : Huruf yang sama pada setiap kolom menunjukkan tidak berbeda nyata menurut Uji Gugus Scott Knott taraf 5\%.

Hasil pengamatan aplikasi $B$. bassiana pada hari ke-1 sampai ke-7 menunjukkan adanya gejala yaitu gerakan mulai lamban, nafsu makan berkurang, tubuh larva mulai mengera dan kaku, warna tubuh berubah jadi coklat kehitaman mengeluarkan bau busuk dan berangsur mati. Hal ini sesuai dengan penelitian Wahyudi (2008) yang menyatakan bahwa aplikasi jamur B. bassiana menyebabkan kehilangan koordinasi sistem gerak, Gejala yang terlihat (Gambar 3) pada larva yang diaplikasikan dengan jamur B. bassiana mengakibatkan larva kurang aktif, lamban dan menunjukkan perubahan warna. Sesuai dengan pernyataan Korlina (2008) yang menyatakan bahwa gejala serangan pada serangga yang terinfeksi sehingga gerakan serangga tidak teratur dan lama-kelamaan melemah, kemudian berhenti sama sekali. Setelah lebih-kurang lima hari terjadi kelumpuhan total dan kematian.

Toksin juga menyebabkan kerusakan jaringan, terutama pada saluran pencernaan, otot, sistem syaraf, dan sistem pernafasan. Konsentrasi yang efektif yang menyebabkan larva menjadi sakit adalah pada taraf konsentrasi $10 \%$ dengan tingkat perubahan kesehatan tertinggi 7,67\%. jamur B. bassiana terlihat larva kaku, kurang aktif dan diikuti oleh perubahan warna tubuh karena dinding tubuhnya telah ditutupi oleh hifa yang berwarna putih seperti kapas. 
Tingkat perubahan kesehatan larva $P$. xylostella yang disajikan pada Gambar 4 menunjukkan hasil dari pemberian ekstrak tumbuhan A. conyzoides cukup signifikan membuat larva sakit yaitu pada taraf perlakuan $\mathrm{H}$ konsentrasi $12,5 \%$ dengan tingkat perubahan kesehatan 7,33\%.

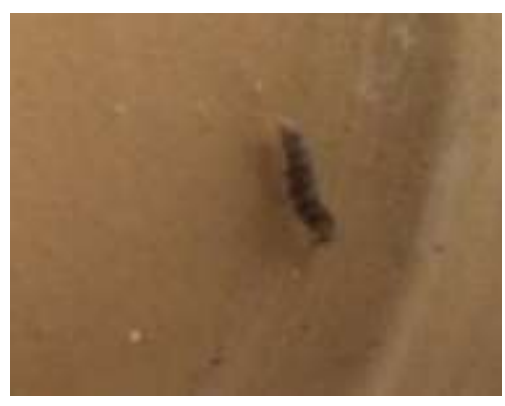

$\mathrm{a}$

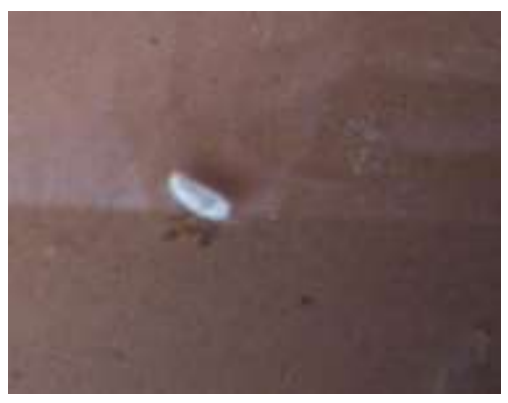

b

Gambar 3. Larva Terinfeksi Jamur B. bassiana (a) Belum Tertutupi Hifa (b)

Hal ini disebabkan karena adanya kandungan metabolit sekunder seperti senyawa flavonoid dan alkaloid pada ekstrak tanaman A. conyzoides. Senyawa flavonoid menyerang bagian syaraf pernafasan hingga menimbulkan kematian. Selain itu, senyawa flavonoid menghambat daya makan (antifeedant) larva $P$. xylostella dengan mengganggu alat pencernaannya Selain flavonoid dan alkaloid, senyawa metabolit sekunder yang terdapat pada ekstrak tanaman A. conyzoides adalah senyawa saponin yang dibuktikan dari buih yang dihasilkan dari pengenceran ekstrak tanaman A. conyzoides dengan larutan aquades ketika larutan dikocok.

Hal ini sesuai dengan apa yang dinyatakan oleh Gunawan dan Mulyani (2004) bahwa saponin sangat mudah ditandai dengan pembentukan larutan koloidal dengan air yang apabila dikocok menimbulkan buih yang stabil. Menurut Marfu'ah (2005) saponin dapat merusak sistem saraf hama, efek nafsu makan menjadi hilang sehingga mengakibatkan hama kurang makan dan akhirnya mati. Selain itu,terdapat juga (Maria, 2017). Menurut Dinata (2009) flavonoid merupakan senyawa kimia yang memiliki sifat insektisida. Flavonoid menyerang bagian syaraf pada beberapa organ vital serangga sehingga timbul suatu pelemahan syaraf, seperti pernapasan dan menimbulkan kematian. Bila senyawa ini masuk ke dalam tubuh serangga, maka alat pencernaannya akan terganggu. Senyawa ini juga bekerja dengan menghambat reseptor perasa pada 
daerah mulut serangga. Hal ini mengakibatkan serangga gagal mendapatkan stimulus rasa sehingga tidak mampu mengenali makanan akibatnya serangga mati kelaparan.



Gambar 4. Grafik Perubahan Kesehatan Larva P. xylostella

senyawa minyak atsiri yang dibuktikan dari bau yang tercium dari hasil ekstraksi tumbuhan $A$. conyzoides yang menyengat. Semakin tinggi dosis jamur $B$. bassiana dan ekstrak tumbuhan $A$. conyzoides yang diberikan maka semakin banyak larva yang menunjukkan gejala penurunan kesehatan yang berangsur mati. Perbedaan antara keduanya adalah pengaruh A. conyzoides langsung terlihat berpengaruh signifikan terhadap jasad sasaran setelah aplikasi (24 jam) sedangkan pengaruh jamur B. bassiana memerlukan waktu yang relatif lebih lama untuk melakukan penetrasi miselium pada kutikula tubuh larva.

\section{Perkembangan Stadia Lanjut}

Hasil analisis statistik menunjukkan terjadi perbedaan yang nyata terhadap hasil analisis tingkat perkembangan stadia lanjut P. xylostella. Hasil analisis data rata-rata perkembangan stadia lanjut $P$. xylostella dapat dilihat pada Tabel 3. Hasil analisis ragam menunjukkan taraf perlakuan A dan D berbeda nyata yang menghasilkan jumlah pupa rata-rata 4,67 dan 0,33 ekor. Perkembangan stadia lanjut larva menjadi pupa mendapatkan nilai paling tinggi yaitu mencapai 
4,67 pada perlakuan A yaitu kontrol, karena disebabkan pengaruh gangguan larva sangat minim apabila dibanding dengan perlakuan yang lain. Kegagalan sebagian larva menjadi pupa diduga karena perbedaan habitat larva yang tidak bisa sama persis dengan dilapangan. Pertumbuhan dan perkembangan serangga dipengaruhi pula oleh faktor abiotik. Kondisi suhu yang tinggi, menyebabkan populasi serangga meningkat, sebaliknya populasi akan menurun pada saat musim hujan (Sarjani, 2009).

Pada taraf perlakuan $\mathrm{B}$ dan $\mathrm{F}$ menunjukkan jumlah rata-rata pupa yang setara dengan perlakuan A yang merupakan kontrol. Hal ini diduga daya rusak $B$. bassiana pada taraf perlakuan $\mathrm{B}$ dan racun pestisida nabati pada perlakuan $\mathrm{F}$ hanya membunuh sedikit $P$. xylostella pada stadia larva, hal ini ditunjang pada parameter mortalitas dan tingkat kesehatan larva $P$. xylostella yang menunjukkan rendahnya tingkat kematian larva sehingga menyebabkan larva hidup dan bisa mengalami proses metamorfosis menjadi pupa masih cukup banyak dan membuat tidak berbeda nyata antara taraf perlakuan B, F dan A.

Tabel 3. Hasil Analisis Perkembangan Stadia Lanjut Umur 8 sampai 14 Hari

\begin{tabular}{|c|c|c|}
\hline \multicolumn{2}{|r|}{ Perlakuan } & $\begin{array}{l}\text { Perkembangan } \\
\text { Larva }\end{array}$ \\
\hline A & Konsentrasi $0 \%$ (100 $\mathrm{ml}$ aquades) & $4,67 \mathrm{~b}$ \\
\hline B & Konsentrasi $7,5 \%(92,5 \mathrm{ml}$ aquades $+7,5 \mathrm{ml} \mathrm{B.} \mathrm{bassiana})$ & $2,67 \mathrm{~b}$ \\
\hline $\mathrm{C}$ & Konsentrasi $10 \%(90 \mathrm{ml}$ aquades $+10 \mathrm{ml}$ B. bassiana $)$ & $1,22 \mathrm{a}$ \\
\hline $\mathrm{D}$ & Konsentrasi $12,5 \%(87,5 \mathrm{ml}$ aquades $+12,5 \mathrm{ml} \mathrm{B.}$ bassiana $)$ & $0,33 \mathrm{a}$ \\
\hline $\mathrm{E}$ & Konsentrasi $15 \%(85 \mathrm{ml}$ aquades $+15 \mathrm{ml}$ B. bassiana $)$ & $1,33 \mathrm{a}$ \\
\hline $\mathrm{F}$ & Konsentrasi 7,5\% (92,5 $\mathrm{ml}$ aquades $+7,5 \mathrm{ml}$ A. conyzoides $)$ & $3,33 \mathrm{~b}$ \\
\hline G & Konsentrasi $10 \%$ ( $90 \mathrm{ml}$ aquades $+10 \mathrm{ml}$ A. conyzoides) & $2,00 \mathrm{a}$ \\
\hline $\mathrm{H}$ & $\begin{array}{lllllll}\text { Konsentrasi } & 12,5 \% & (87,5 & \mathrm{ml} & \text { aquades+12.5 } & \mathrm{ml} & A . \\
\text { conyzoides }) & & & & & & \end{array}$ & $1,61 \mathrm{a}$ \\
\hline
\end{tabular}

$\overline{\text { Keterangan : Huruf yang sama pada setiap kolom menunjukkan tidak berbeda }}$ nyata menurut Uji Gugus Scott Knott taraf 5\%.

Gambar 5 menunjukkan aplikasi jamur B. bassiana pada semua taraf perlakuan yaitu $\mathrm{C}, \mathrm{D}$, dan $\mathrm{E}$ menunjukkan hasil yang berbeda nyata dengan 
kontrol. Hal ini dikarenakan jamur B. bassiana terus berkembang dan menginfeksi inang sampai fase akhir. Tingkat kerusakan yang dibuat oleh jamur B. bassiana pada inang tidak terlalu terlihat pada hari ke-1 dan sangat terlihat pada hari ke-7 sehingga jumlah larva yang tersisa dan meneruskan siklus hidupnya menjadi sangat sedikit.

Aplikasi ekstrak tumbuhan A. conyzoides terlihat pada taraf perlakuan G dan $\mathrm{H}$ memiliki perbedaan yang signifikan dengan taraf perlakuan $\mathrm{F}$. Hal ini karena dosis ekstrak A. conyzoides pada taraf perlakuan $\mathrm{G}$ dan $\mathrm{H}$ lebih tinggi sehingga memiliki daya racun yang lebih tinggi terhadap larva.

Dosis yang tinggi mempengaruhi siklus hidup larva $P$. xylostella yang seharusnya larva instar IV tersebut menjadi pupa dan menjadi kepompong tetapi terhambat siklus hidupnya sehingga mengakibatkanlarva mati dan tidak berkembang menjadi kepompong / pupa kepompong Hal ini sesuai dengan pernyataan Sudarmo (2005) yang menyatakan bahwa salah satu cara kerja pestisida nabati sangat spesifik yaitu dapat merusak perkembangan telur, larva, dan pupa. Sehingga siklus hidup/metamorfosis larva $P$. xylostella akan terganggu dan terputus.

berikut hasil analisis perkembangan stadia lanjut :

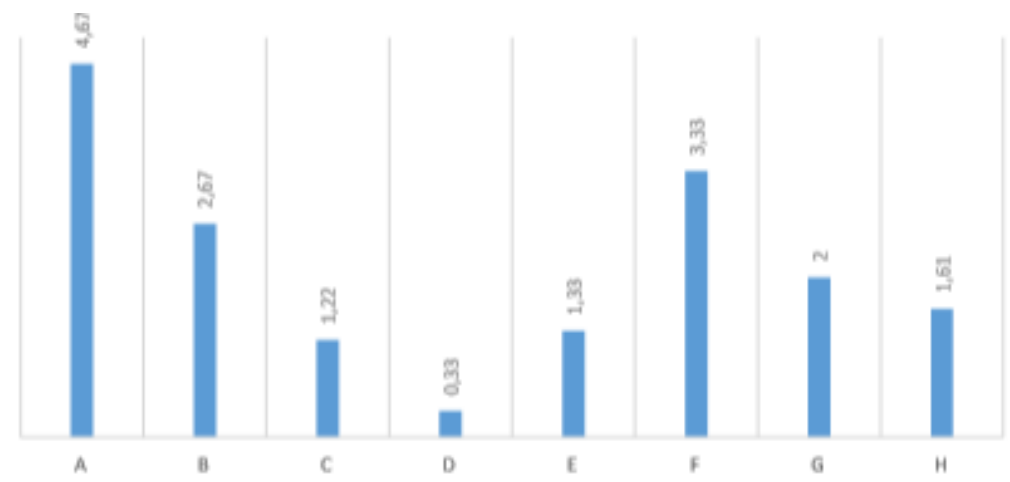

Gambar 5. Grafik Perkembangan Stadia Lanjut

\section{KESIMPULAN}

Aplikasi berbagai konsentrasi jamur B. bassiana dan ekstrak umbuhan A.conyzoides berpengaruh nyata dalam pengendalian larva $P$. xylostella. Pengaruh aplikasi jamur B. bassiana pada taraf konsentrasi $10 \%$ terhadap mortalitas larva merupakan konsentrasi paling efektif dan efisien karena mampu membunuh larva 
76,67\% pada hari ke-7, membuat larva sakit sebanyak 7,67 ekor pada perubahan kesehatan, dan meminimalisir perubahan stadia lanjut larva sebanyak 1,22 ekor. Aplikasi A. conyzoides konsentrasi $12,5 \%$ merupakan dosis yang paling tinggi tingkat mortalitas larva $P$. xylostella karena mampu membunuh larva sebanyak 73,33\% pada hari ke-7, membuat larva sakit sebanyak 7,33 ekor pada perubahan kesehatan, dan meminimalisir perubahan stadia lanjut larva sebanyak 1,61 ekor.

\section{DAFTAR PUSTAKA}

Andreina, Maria. 2017. Uji Toksisitas Ekstrak Tanaman Ageratum conyzoides L. Sebagai Insektisida Nabati Terhadap Mortalitas Hama Ulat Kubis (Plutella xylostella L.). (Skripsi). Universitas Sanata Dharma. Yogyakarta.

Dinata, A., 2009, Atasi Jentik DBD dengan Kulit Jengkol, Diunduh dari http://arda.students- blog.undip.ac.id/2009/10/18/atasi- jentik-bddengan-kulit-jengkol, Diakses tanggal 22 April 2018.

Gunawan dan Mulyani, 2004, Ilmu Obat Alam, Penebar Swadaya: Bogor.

Husodo H. S. 2017. Ulat Daun Kubis Serang Lahan Pertanian di KBB. www.pikiran-rakyat.com/bandung- raya/2017/01/20/ulat-daun--kubisserang-lahan-pertanin-di-kbb- 391172. (diakses 12 april 2018).

Kardinan, A. 2004. Pestisida Nabati: Ramuan dan Aplikasi, Penebar Swadaya, Jakarta.

Kartosuwondo U. 1994. Populasi Plutella xylostella (L.) (Lepidoptera: Yponomeutidae) dan parasitoid Diadegma semiclausum Hellen (Hymenoptera: Ichneumonidae) pada kubis dan dua jenis Brassicaceae liar. Bul HPT 7.

Korlina E, Mahfud, C Rachmawati D, Sarwono \& Fatimah S. 2008. Pengkajian Efektifitas Cendawan Beauveria bassiana Terhadap Perkembangan Hama dan Penyakit Tanaman Krisan. Prosiding Seminar Pemberdayaan Petani Melalui Informasi dan Teknologi Pertanian. KP. Mojosari-16 Juli 2008. Kerjasama BPTP Jatim, Faperta Unbra, Diperta Prov, Bappeda. 
Marfu'ah, P., 2005, Perisai itu Bernama Kambing Jantan, Majalah Trubus 425 Th. XXXVI, Jakarta.

Mutiah Sari, Lahmuddin Lubis, dan Yuswani Pangestiningsih. 2013. Uji Efektifitas beberapa Insektisida Nabati untuk Mengendalikan Ulat Grayak (Spodoptera litura F.) (Lepidoptera : Noctuide) di Laboratorium. Fakultas Pertanian Universitas Sumatera Utara. Medan.

Novizan. 2002. Membuat dan Memanfaatkan Pestisida Ramah Lingkungan. Agromedia Pustaka. Jakarta.

Purba, S. 2007. Uji Efektivitas Ekstrak Daun Mengkudu (Morinda citrifolia) terhadap Plutella xylostella L. (Lepidoptera : Plutellidae) di Laboratorium. Skripsi. Universitas Sumatera Utara. Medan.

Rukmana, R. 1994. Budidaya Kubis dan Brokoli. Kanisius, Yogyakarta. Sastrosiswoyo, S., Uhan, T., Sutarya, R., 2005. Penerapan Teknologi PHT pada Tanaman Kubis. Balai Penelitian Sayuran. Lembang. Bandung.

Sastrosiswojo B, dan W. Setiawati. 1993. Hama-hama tanaman kubis dan cara pengendaliannya. In: A.H. Permadi dan S. Sastrosiswojo (eds). Kubis. Balitbang Pertanian dan Balai Penelitian Hortikultura, Bandung.

Sudarmo, S., 2005, Pestisida Nabati Pembuatan Dan Pemanfaatannya, Kanisius, Yogyakarta.

Suprapto, Suroso. 1998. Pengaruh Konsentrasi Cendawan Beauveria bassiana vuill (curculionidae: Coleoptera). Seminar Nasional PEI. Lampung.

Susanti, S. Wibowo, L. Indrayati. 2016. Kompatibilitas Jamur Entomopatogen Beauveria bassiana Vuill. dan Pestisida Nabati Ekstrak Daun Babadotan Untuk Mengendalikan Hama Kepik Hijau di Laboratorium. Universitas Lampung. Lampung.

Untung, K., 2001, Pengantar Pengelolaan Hama Terpadu, Gadjah Mada University Press, Yogyakarta. 
Wahyudi. 2008. Jamur Patogen Serangga Sebagai Bahan Baku Insektisida Pemanfaatan Mikroba dan Parasitoid dalam Agroindustri Tanaman Rempah dan Obat. Perkembangan Teknologi Tanaman Rempah dan Obat (XII), 21-28pp.

Winasa IW, Herlinda S. 2003. Population of diamondback moth, Plutella xylostella L. (Lepidoptera: Plutellidae), and its damage and parasitoids on brassicaceous crops. Di dalam: Prosiding International Seminar on Organic Farming and Sustainable Agriculture in the Tropics and Subtropics. Palembang Okt ober 8-9, 20 